\title{
PKM PASAR SYARIAH ULUL ALBAB
}

\section{PKM OF PASAR SYARIAH ULUL ALBAB}

\author{
Idel Waldelmi, Wita Dwika Listihana, Afvan Aquino \\ Universitas Lancang Kuning \\ Jln. Yos Sudarso KM 08 Rumbai Telp. (0761) 52581 \\ idelwaldelmi@unilak.ac.id
}

\begin{abstract}
Abstrak
Lembaga keuangan syariah / BMT adalah lembaga usaha yang berusaha memberi manfaat dan bukan lembaga sosial. Permasalahan yang dihadapi pedagang dalam mengakses modal dari lembaga keuangan yang diakui oleh pedagang memang sulit dan rumit. Oleh karena itu alternatif yang dimanfaatkan Padagang adalah jasa pelapas bagi para rentenir. Dari hasil pelayanan yang telah dilakukan, pedagang mulai menyadari modal yang diperolehnya, oleh karena itu upaya yang dilakukan tidak lain adalah mendirikan lembaga keuangan syariah / BMT di lingkungan pasar syariah maupun dari jasa yang dilakukan pada ulul. Pasar syariah albab bersama mitra penyuluhan hal ini kepada para pelaku usaha yaitu para pedagang di pasar sangat membantu para pedagang untuk mengenal dan memahami untuk dapat mengamalkan pentingnya lembaga keuangan syariah / BMT yang sesuai dengan syariah dan keberadaannya. adanya kepercayaan yang tinggi dari para pedagang / pelaku usaha untuk segera mewujudkan keinginan para pelaku usaha / pedagang untuk dapat mendirikan lembaga keuangan syariah / BMT di lingkungan pasar syariah. Pada intinya lembaga keuangan syariah akan memberikan kesempatan kepada pelaku usaha / perdagangan untuk ikut serta dalam berdagang untuk mendirikan lembaga keuangan syariah / BMT, penggunaan dan akses BMT oleh para pedagang tentunya akan sangat membantu bagi para pelaku usaha pedagang.
\end{abstract}

Kata Kunci: BMT, Pedagang Pasar

Abstract

Islamic financial institutions / BMTs are business institutions that strive to benefit and not social institutions. The constraint faced by traders in access to obtain capital from financial institutions, recognized by traders is difficult and complicated. Therefore the alternative utilized by seller is the pelapas service for capital / loan sharks. From the results of service that have been carried out, traders are beginning to realize the capital they get, therefore the efforts made are none other than establishing Islamic / BMT financial institutions in the sharia market environment as well as from the services performed on the ulul albab sharia market with partners with counseling this to businesspeople, namely traders in the market, is very helpful for traders to get to know and understand to be able to practice the importance of sharia financial institutions / BMTs that are in accordance with sharia and the existence of high confidence from traders / business people to immediately actualize their desires business actors / traders to be able to establish Islamic financial institutions / BMTs in the Islamic market environment. At the point of sharia financial institutions will provide opportunities for business / trade actors to participate in trading to establish financial institutions sharia / BMT, the use and access of BMTs by the traders will certainly be very helpful for traders' businesses

Keywords: BMT, Market Traders

\section{PENDAHULUAN}

Pasar syariah ulul albab merupakan satu satunya pasar syariah yang ada di bumi lancang kuning ini, yang terletak di Desa Tanah Merah Kecamatan Siak Hulu Kabupaten Kampar Riau. Pasar syariah ulul albab merpakan pasar yang di kelola secara pribadi yakni Bapak Jefri Noor, yang masa itu menjabat sebagai Bupati, dan dimasa beliau inilah pasar syariah ulul albab di dirikan.

Profil pasar syariah ulul ini bisa dilihat dari kondisi pedagang, dimana kondisi dilapangan hampir seluruh pedagang mengungkap ketidakmampuan secara financial membuat usaha untuk berkembang, dengan segala keterbatasan pedagang dalam masalah modal, bisa dikatakan pedagang mengandal rekan sesama pedagang, rekanan/sales yang menawarkan produk, agen/ distributor, rentenir, koperasi yang di kelola langsung oleh pemilik pasar atau lembaga keuangan seperti perbankan baik bank syariah maupun konvensional.

[5] Pertanian, 2007 Kekurangan modal selalu menjadi masalah klasik bagi sebagian besar pelaku 
Jurnal Pengabdian Masyarakat J-DINAMIKA, Vol. 5, No. 2, Desember 2020

P-ISSN: 2503-1031, E-ISSN: 2503-1112

usaha, termasuk pedagang. Sementara itu, masih banyak 
potensi dana di perbankan yang belum banyak dimanfaatkan untuk sektor pembiayaan/kerdit bagi para pelaku usaha. Untuk menjembatani kepentingan pedagang dan pihak perbankan diperlukan lembaga mediator agar kedua pihak dapat menjalin kerja sama usaha yang saling menguntungkan.

Permasalahan yang dihadapi UMKM disemua daerah hampir sama, yaitu; keterbatasan modal kerja, kualitas sumber daya manusia yang rendah, produktivitas dan kualitas produk yang rendah, serta minimnya penguasaan ilmu pengetahuan dan teknologi [3] Delima Sari Lubis, 2016).

Lembaga keuangan mikro syariah Baitul Mal wa Tamwil (BMT) adalah kelompok swadaya masyarakat sebagai lembaga ekonomi rakyat yang berupaya mengembangkan usaha-usaha produktif dan investasi dengan konsep utamanya adalah sistem bagi hasil untuk meningkatkan kualitas ekonomi pengusaha kecil dalam upaya pengen- tasan kemiskinan. (Mu'alim dan Abidin, Jurnal "Millah" Vol IV, 2 Jan 2005). [7] Sholahuddin, 2007. Lembaga keuangan mikro merupakan salah satu pilar dalam proses intermediasi keuangan. [2] Baskara, 2013 Keuangan mikro dibutuhkan oleh kelompok masyarakat kecil dan menengah baik untuk konsumsi maupun produksi serta juga menyimpan hasil usaha mereka.

Dengan adanya fenomena tersebut, lembaga keuangan mikro syariah BMT mengembangkan pemikiran untuk memberikan berbagai macam pembiayaan. Memang banyak dana yang disalurkan oleh lembaga keuangan mikro syariah kepada para pengusaha lapisan menengah ke bawah. Hal tersebut terbukti berdasarkan harian Republika (24/02/2007, hal:19) sampai bulan Desember 2006, 90 persen rata-rata asset BMT di atas Rp 1 miliar. Namun demikian, lembaga keuangan mikro syariah Baitul Maal wat Tamwil apakah sudah berperan dalam meningkatkan keuntungan para pelaku usaha kecil ? Hal tersebut menarik untuk dicermati dan dibuktikan secara empiris.

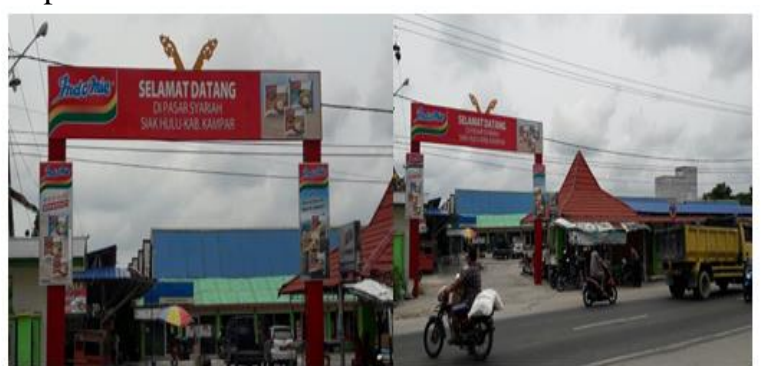

Gambar 1. Gerbang masuk dan keluar pasar Syariah Ulul Albab serta aktifitas pedagang.

Melihat kondisi perekonomian khususnya pedagang pasar syariag ulul albab yang cukup baik, dan kebijakan - kebijakan pemerintah kabupaten Kampar kecamatan siak hulu desa tanah merah yang cukup berpihak untuk peningkatan perekonomian rakyat. Dengan demikian, dapat membuka peluang untuk pelaku usaha mikro, kecil dan menengah (UMKM) dalam mengembangkan bisnisnya. Dalam meningkatkan pertumbuhan kegiatan bisnisnya, UMKM tentu akan menemui kendala didalamnya. Salah satu yang menjadi permasalahan klasik yang dihadapi oleh UMKM adalah kendala terkait permodalan. UMKM mayoritas terkendala masalah administrasi ketika mengajukan tambahan modal kepada pihak perbankan, sehingga UMKM sering disebut ini tidak bankable.

[4] Oktafia, 2017 Lembaga keuangan mikro syariah memiliki dua fungsi yang melekat, yaitu fungsi sosial dan fungsi bisnis. Dengan potensi fungsi lembaga keuangan mikro yang sangat besar ini, dapat dikembangkan untuk memperkuat perekonomian masyarakat melalui pembiayaan mikro. Dengan demikian, dapat membantu pemerintah pula dalam mewujudkan pemerataan kesejahteraan bagi seluruh masyarakat. Hal ini berkaitan dengan bahwa, salah satu upaya yang dilakukan oleh pemerintah untuk mengentaskan kemiskinan adalah dengan memperkuat peran lembaga keuangan mikro dalam penyediaan modal untuk berwirausaha. Kebijakan-kebijakan pemerintah yang terkait sistem keuangan pun, harus berpihak kepada rakyat kecil dan pelaku usaha mikro. Usaha Mikro, Kecil dan Menengah (UMKM), merupakan bagian penting dalam memperkuat perekonomian bangsa, sebab sektor UMKM ini memiliki porsi terbesar dalam skala bisnis di Indonesia.

Hasil penelitian ini menunjukkan bahwa pembiayaan BMT pada pedagang pasar tradisional yang menjadi anggota BMT di Bantul, tidak berpengaruh signifikan terhadap persepsi pedagang tersebut tentang perkembangan usahanya dan peningkatan kesejahteraannya (walaupun arahnya sudah benar positif). Namun demikian, persepsi pedagang tersebut tentang perkembangan usahanya berpengaruh positif signifikan terhadap persepsi peningkatan kesejahteraannya. Dapat dikatakan bahwa berdasar persepsi para pelaku usaha mikro pedagang di pasar-pasar tradisional kabupaten Bantul sebagai berikut: Secara umum BMT sudah memiliki peran positif terhadap perkembangan usaha dan peningkatan kesejahteraan, namun terlalu kecil atau tidak signifikan(Prastiawati et al., 2016).

Lembaga keuangan mikro syariah dijelaskan sebagai suatu sistem keuangan berbasis Islam atau yang dikenal dengan syariah. LKMS yang dimaksudkan disini adalah Baitul Mal wat Tamwil (BMT). Secara kuantitatif, lembaga ini mengalami perkembangan yang sangat pesat. Perkembangan BMT yang pesat ini terjadi karena tingginya kebutuhan masyarakat akan jasa 
intermediasi keuangan, tetapi di sisi lain akses ke dunia perbankan yang lebih formal relatif sulit. BMT memberikan solusi bagi masyarakat untuk mendapatkan dana dengan mudah dan cepat, terhindar dari jerat rentenir, dan mengacu pada prinsip syariah. LKMS terbilang mengalami perkembangan paling menonjol selama lima belas tahun terakhir, jika dibandingkan dengan berbagai lembaga keuangan syariah lainnya di Indonesia [9] Zubair, 2016).

(Anggraeni, Puspitasari, Ayubbi, \& Wiliasih, 2013)Usaha Mikro, Kecil dan Menengah (UMKM) memiliki peranan cukup besar bagi pendapatan domestik bruto Indonesia dan penyerapan tenaga kerja. Namun sebagian besar UMKM menghadapi kendala permodalan dan keterbatasan akses pada lembaga keuangan formal. Baitul Maal Wat Tamwil (BMT) merupakan salah satu lembaga keuangan mikro syariah yang dapat menjadi solusi kendala permodalan pada UMKM dan terhadap pembiayaan BMT. Pembiayaan mikro syariah BMT yang diberikan mampu meningkatkan keuntungan UMKM sebesar 6,21 persen dari keuntungan usaha rata-rata $\mathrm{Rp} 79,12$ juta menjadi Rp 84,03 juta per tahun.

Berdasarkan bahasan yang dibahas diatas didapatkan data/ informasi, pedagang lebih suka dengan cara lebih cepat mendapatkan modal, apakah melalui koperasi yang notabene lebih singkat waktu pelunasannya serta pinjaman terbatas dan, rentenir

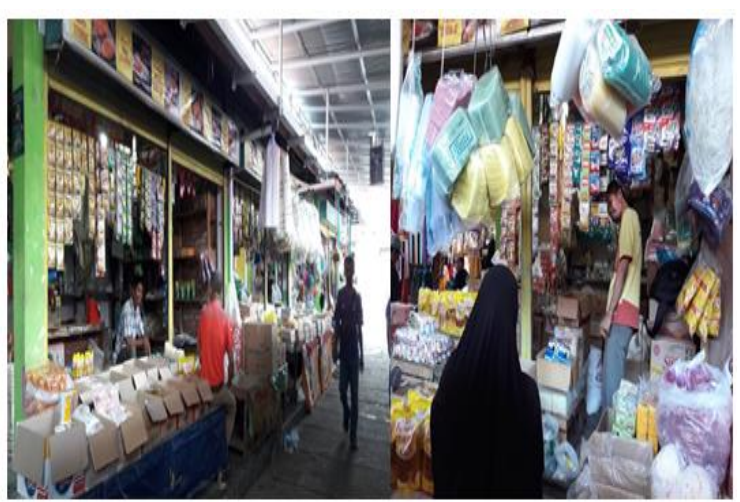

Gambar 2. Aktifitas transaksi jual beli yang di lakukan di pasar syariah ulul albab

yang dengan bermodalkan KTP saja dapat mendapatkan pinjaman modal walaupun dengan meminjam dengan cukup berat dan sesama pedagang yang memilki kelebihan akan modal seperti barang di jual di berikan ke pedagang lainnya dengan keuntungan yang saling berbagi. Ini menjadi kendala sendiri oleh pedagang, karena informasi keuangan yang didapatkan hanya berkutat ditempat dan sulitnya akses untuk mendapatkan modal yang lebih besar serta berkah.

Oleh karena itu, perlu dicari alternatif permodalan untuk para pelaku UMKM, di pasar syariah ulul albab yang mana hasil pengabdian sebelumnya yang telah dilaksanakan[8] Wita Dwika Listihana, Idel Waldelmi, 2019 perlunya dihadirkan dari pihak lembaga keuangan /BMT untuk semakin meningkatkan pemahaman pedagang akan lembaga keuangan syariah/BMT. Hal inilah, yang dapat membuka peluang seluas-luasnya bagi UMKM untuk mengakses permodalan melalui LKMS/BMT.

Permasalahan Mitra : Kurangnya pengetahuan mitra akan permodalan yang sesuai dengan syariah dan Minimnya akses mitra untuk mendapatkan permodalan yang syariah, Ketergantungan pedagang terhadap pembiayaan yang tidak sesuai syariah seperti Koperasi, rentenir, atau lembaga keuangan /pernbankan konvensional dan Munculnya statement dari pedagang bahwasannya bank syariah dan konvensional sama saja dan lebih sulit dalam memberikan pembiayaan.

\section{II.METODE}

Untuk memberikan solusi kepada mitra ( mengimplementasikan gagasan) maka ada beberapa metode yang ditawarkan untuk menyeleseikan persoalan mitra yakni : Melakukan Penyuluhan akan pentingnya mendapatkan modal yang jelas sumbernya dan lebih berkah ( Modal syariah, Modal yang tidak halal/konvensional, Rentenir itu merugikan bukan menguntungkan), Menyamakan persepsi dengan para pedagang yang hadir akan modal yang di dapatkan harus baik dan halal serta cara mendapatkannya, dan Memberikan kesempatan kepada para pedagang untuk mengajukan permasalahan mereka dalam bentuk diskusi akan pertanyaan yang diajukan, Menyebarkan quisioner sebelum dan sesudah penyampaian materi/ penyuluhan kepada para pedagang.

\section{HASIL}

Pengabdian ini merupakan tindak lanjut dari pengabdian sebelumnya dengan tema Permodalan Pedagang dipasar syariah ulul albab, dimana pedagang dalam pengabdian tersebut meminta agar bisa untuk menghadirkan lembaga keuangannya. Berdasarkan hasil pengabdian yang dilaksanakan pada tanggal 23 Juni 2019 lalu di Pasar Syariah Ulul Albab Desa Pandau Jaya Dan Desa Tanah Merah Kecamatan Siak Hulu Kabupaten Kampar -Riau tentang "Pasar Syariah Ulul Albab Desa Tanah Merah Kec. Siak Hulu Kab. Kampar Riau", maka untuk mengukur tingkat keberhasilan/dilaksanakannya kegiatan yang telah di laksanakan dengan cara melakukan evaluasi (2) tahapan yakni sebelum (pre tes) dan sesudah (pos tes)serta diskusi yang cukup panjang antara pedagang pasar syariah dan lembaga keuangan (BMT). 


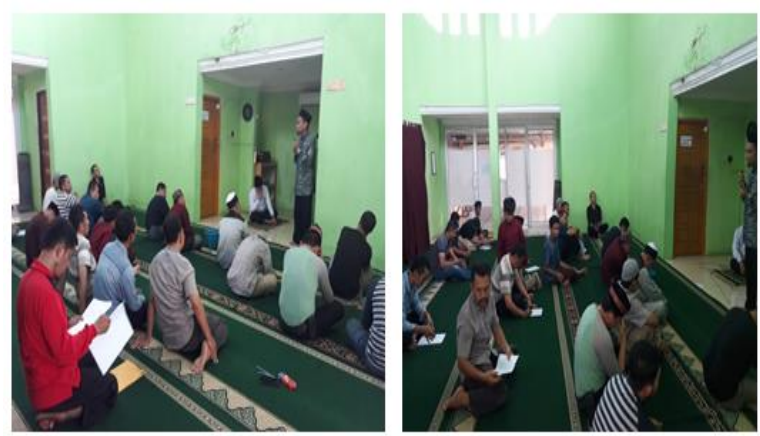

Gambar 3. Sosialisasi BMT/koperasi syariah oleh Ade Chandra/praktisi BMT/Pendiri BMT

Kegiatan evaluasi ini bertujuan untuk melihat seberapa jauh pengetahuan dan keinginan dari peserta pengabdian kepada pedagang pasar syariah ulul albab mampu memahami akan materi penyuluhan yang di berikan. Indikator tingkat keberhasilan kehadiran peserta setelah di sampaikannya informasi melalui corong informasi di musholla di pasar syariah tersebut. Kondisi ini di nilai cukup maksimal dan dinilai berhasil karena targetnya yang diinginkan jemaah yang melaksanakan sholat pada waktu selesei sholat dzuhur di laksanakan dimana dari 30 pree test dan post test yang mengembalikan dengan mengisi lembaran sebanyak 18 peserta.

\section{IV.PEMBAHASAN}

Setelah melaksanakan program pengabdian kepada masyarakat khususnya pada pedagang pasar syariah ulul albab, dilakukan evaluasi tentang 4 hal yakni, lembaga keuangan syariah/ BMT, Pprbedaan lembaga keuangan syariah dan non syariah, produk - produk dari lembaga kuangan syariah dan pendirian akan lembaga keuangan syariahdi pasar syariah ulul albab.

Baitul Maal Wat Tamwil (BMT) atau Balai Usaha Mandiri Terpadu adalah lembaga keuangan mikro yang dioperasikan dengan prinsip bagi hasil, menumbuhkembangkan usaha mikro dalam rangka mengangkat derajat dan martabat serta membela kepentingan kaum fakir miskin, ditumbuhkan atas prakarsa dan modal awal dari tokoh-tokoh masyarakat setempat dengan berlandasan pada sisitem ekonomi yang salam: keselamatan (berintikan keadilan), kedamaian, dan kesejahteraan.

Peran BMT dimasyarakat adalah 1). Menjauhakan masyarakat dari praktik ekonomi non syariah, aktif melakukan sosialisasi ditengah masyarakat tentang arti pentingnya sistem ekonomi islam. Hal ini bisa dilakukan dengan pelatihanpelatihan mengenai cara transaksi secara islam, misalnya dilarang mengurangi timbangan, bukti transaksi, jujur terhadap konsumen, dan sebagainya. 2) Melepas ketergantungan pada rentenir, masyarakat yang masih tergantung rentenir ini disebabkan karenan rentenir mampu memenuhi keinginan masyarakat dalam memenuhi dana dengan segera. Maka BMT harus mampu melayani masyarakat dengan baik. Misalnya tersedia dana setiap saat, birokrasi yang sederhana, dan sebagainya. 3) Melakuakan pembinaan pendanaan usaha kecil, BMT harus bersikap aktif dalam menjalankan fungsi sebagai lembaga keuangan mikro, misalnya dengan jalan pendampingan, pembinaan, penyuluhan, dan pengawasan terhadap usaha nasabah atau masyarakat umum. 4) Menjaga keadilan ekonomi masyarakat, fungsi BMT langsung berhadapan dengan masyarakat yang kompleks dituntut harus pandai bersikap. Oleh karena itu, langkah-langakah untuk melakuakan evaluasi yang harus diperhatikan misalnya, dalam masalah pembiayaan, BMT harus memperhatikan kelayakan nasabah dalam hal golongan nasabah dan jenis pembiayaan yang ingin diajukan oleh nasabah.

Adapun Ciri-ciri utama BMT, yaitu: 1) Brorientasi bisnis, mencari laba bersama, meningkatkan pemanfaatan ekonomi paling banyak untuk anggota dan lingkungannya 2). Bukan lembaga sosial tetapi dapat dimanfaatkan untuk mengefektifkan penggunaan zakat, infak, dan shadaqoh bagi kesejahteraan orang banyak 3). Ditumbuhkan dari bawah berlandaskan peran serta masyarakat di sekitarnya 4). Milik bersama masyarakat kecil dan bawah dari lingkungan BMT itu sendiri, bukan milik orang seseorang atau orang dari luar masyarakat tersebut.

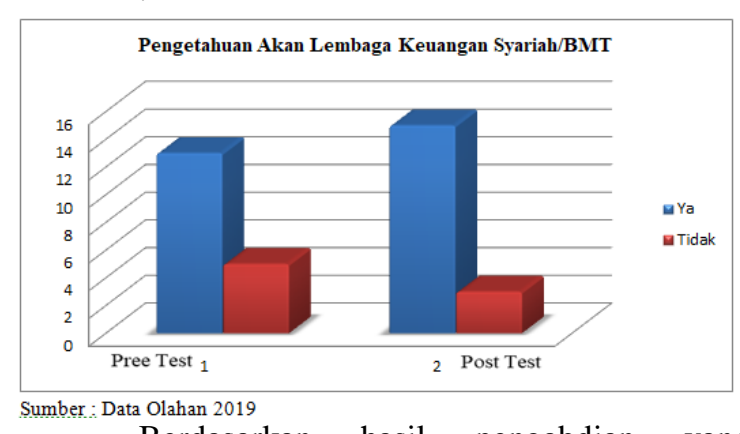

Berdasarkan hasil pengabdian yang dilaksanakan pada tanggal 23 juni 2019 di pasar syariah ulul albab diketahui bahwa sejauh mana pedagang mengetahui lembaga keuangan syariah /BMT, yang selama ini diketahui dari hasil pree test sebelum dilaksanakannnya pengabdian kepada para pedagang diketahui bahwa $60 \%$ dari pedagang mengetahui dan setelah pengabdian diketahui terjadi perubahan kearah significant yakni meningkat sebanyak $80 \%$ dan ini menunjukkan bahwasannya tingkat pengetahuan dari peserta meningkat dengan adanya kegiatan pengabdian ini.

Dengan adanya informasi tentang lembaga keuangan syariah kepada pedagang yang berada di pasar syariah tentunya akan memberikan informasi yang yang akan berdampak positif, dari kebiasaan hanya tahunya koperasi konvensional yang yang 
secara tidak langsung sama saja dengan rentenir. Dengan adanya BMT ini diharapkan adanya perubahan pola pikir akn ketergantungan lembaga keuangan syariah BMT.

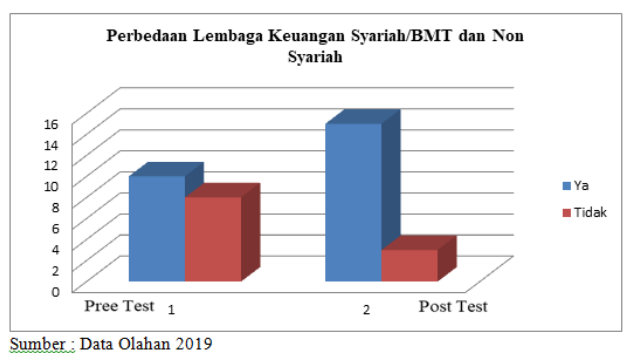

Berdasarkan hasil pengabdian yang telah dilaksanakan didapatkan hasil yang menunjukkan bahwasanya sebelum dilaksanakannya pengabdian didapatkan hasil dai sebaran pree test sebanyak $50 \%$ pedagang tidak bisa membedakan atau tidak mengetahui dan setelah di laksanakan pengabdian melalui sosialisasi lembaga keuangan syariah/BMT di dapatkan data dari sebaran post test sebanyak 85 $\%$ sudah mengetahui dan bisa membedakan antara lembagan keuangan syariah dan lembaga keuangan konvensinal.

Lembaga keuangan syariah dan lembaga keuangan konvensional sama sama lembaga bisnis yang juga ignin mendapatkan keutungan. Namun perlu diketahui lembaga keuangan syariah tidak mengandalkan bunga namun dengan system bagi hasil, adanya aqad /kesepakatan bersama antara pemodal dan pemilik modal dalam hal penyaluran modal dan keuntungan, perlu juga diketahui lembaga keuangan syariah/BMT juga sama dengan koperasi kebanyakkan yakni berbasis anggota /dari anggota untuk anggota sedangkan lembaga koperasi yang ada saat ini sama saja dengan jasa pelepas modal/rentenir, dimana hal ini dibenarkan pedagang yang ada di pasar syariah.

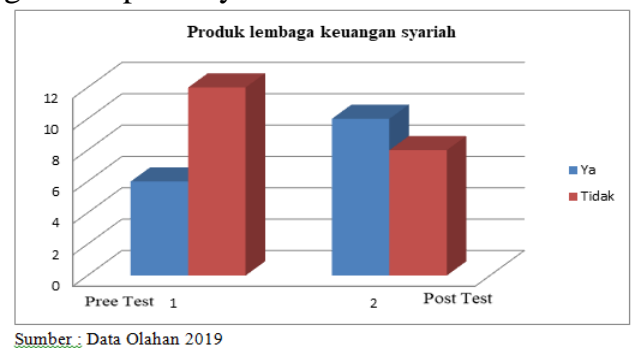

Berdasarkan hasil pengabdian yang telah dilaksanakan didapatkan hasil yang menunjukkan bahwasanya sebelum dilaksanakannya pengabdian didapatkan hasil dari sebaran pree test sebanyak $65 \%$ pedagang tidak mengetahui produk dari lembaga keuangan syariah/BMT dan setelah dilaksanakan pengabdian melalui sosialisasi lembaga keuangan syariah/BMT di dapatkan data dari sebaran post test sebanyak $60 \%$ sudah mengetahui dan bisa membedakan antara produk keuangan syariah dan konvensional.
Hal ini akan menjadi sangat penting diketahui oleh pedagang, akan sumber permodalan yang mereka dapatkan untuk kelangsungan usaha mereka, modal memang akan sangat menentukan keberlanjutan usaha dagang yang mereka geluti setiap harinya namun juga perlu di ketahui apakah modal dan usaha yang lakukan setiap harinya mendapatkan keberkahan atau tidak. Pedagang sendiri juga menyadari mereka bisa dikatakan ketergantungan dengan jasa pelepas modal/rentenir, banyak factor yang menyebabkan mereka butuh dengan rentenir. Hal inilah yang sampai saat ini jasa pelepas modal menjadi alternative dan tumbuh dengan suburnya di pasar syariah. Argument yang muncul dari para pedagang dari ketidaktahuan akan produk lembaga keuangan syariah yakni tidak tahu dan tidak faham akan system dari lembaga keuangan syariah/BMT.

Adapun produk dari lembaga keuangan syariah/BMT yakni Mudharabah adalah salah satu jenis pembiayaan untuk usaha atau proyek (dapat disejajarkan dengan instrumen pembiayaan obligasi / quasi equity seperti obligasi konversi). Pengusaha proyek adalah pemegang amanah terhadap modal yang diterima dari pemilik modal (venture capital company) di mana modal merupakan titipan/amanah dalam konsep wadiah yang dapat dimanfaatkan untuk memperoleh keuntungan. Pengusaha saat melakukan proyek yang berkaitan dengan Al Mudharabah adalah wakil pemilik modal, dan jika pengusaha memperoleh keuntungan maka pengusaha bertindak sebagai rekan pemilik modal, sehingga keuntungan tersebut harus dibagikan sesuai dengan prinsip musyarakah yang mengharuskan adanya bagi hasil yang adil antara rekan perkongsian.

Bagi hasil keuntungan ini dengan Nisbah (profit sharing ratio / perbandingan, misalnya 66\%: $33 \%$ untuk pemilik modal : pengusaha) ditentukan pada kesepakatan/perjanjian awal. Modal disediakan seluruhnya oleh pemilik modal sampai suatu masa tertentu di mana modal tersebut dikembalikan secara utuh. Contoh Perhitungan Praktis Pembiayaan Mudharabah Seorang pedagang yang memerlukan modal untuk berdagang dapat mengajukan permohonan untuk pembiayaan bagi hasil seperti mudharabah, di mana bank bertindak selaku shahibul maal (penyandang dana) dan nasabah selaku mudharib (pengelola). Caranya adalah dengan menghitung dulu perkiraan pendapatan yang akan diperoleh nasabah dari proyek yang bersangkutan. Misalnya, dari modal Rp30.000.000,00 diperoleh pendapatan Rp5.000.000,00 per bulan. Dari pendapatan ini harus disisihkan dahulu untuk tabungan pengembalian modal, misalnya Rp2.000.000,00. Selebihnya dibagi antara bank dengan nasabah dengan kesepakatan di muka, misalnya $60 \%$ untuk nasabah dan $40 \%$ untuk 
bank. (Muhammad Gunawan Yasni, SE Ak., MM : 2004).

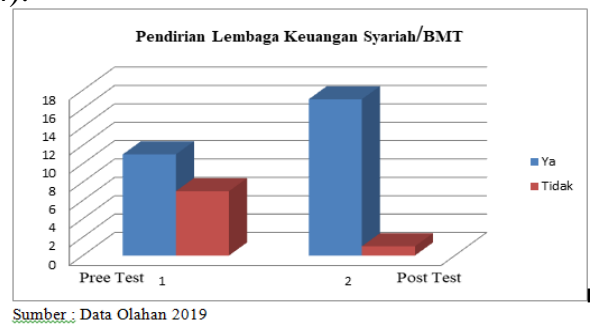

Berdasarkan hasil pengabdian yang telah dilaksanakan didapatkan hasil yang menunjukkan bahwasanya sebelum dilaksanakannya pengabdian didapatkan hasil dari sebaran pree test sebanyak $65 \%$ pedagang tidak mengetahui produk dari lembaga keuangan syariah/BMT dan setelah dilaksanakan pengabdian melalui sosialisasi lembaga keuangan syariah/BMT di dapatkan data dari sebaran post test sebanyak $60 \%$ sudah mengetahui dan bisa membedakan antara produk keuangan syariah dan konvensional.

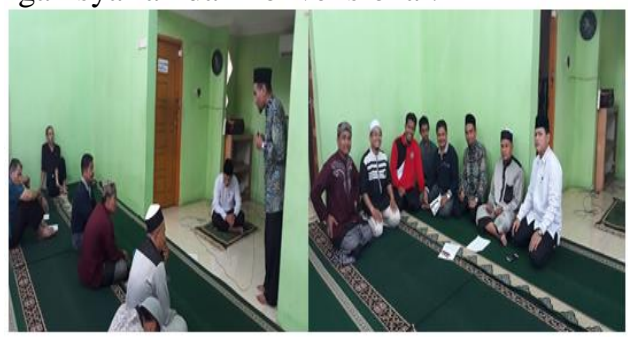

Gambar 5.5. Diskusi dan dilanjutkan setelah diskusi antara pedagang dan pemateri dalam sosialisasi lembaga keuangan syariah /BMT

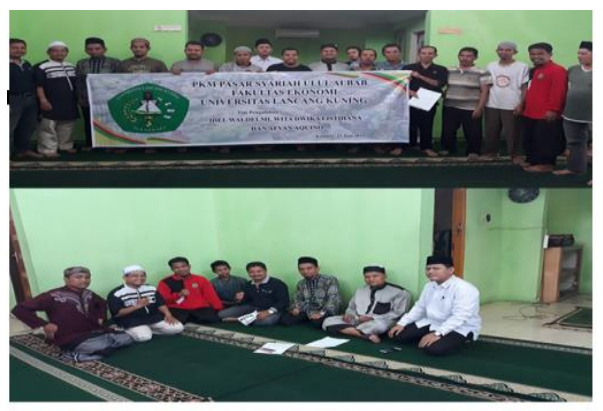

Gambax 5.6. Fhoto bersama para pelaku usaha/ pedagang setelah penyampaian materi oleh Bapak Ade handra (Pendin pengelola BMT) dan dilanjutkan diskusi denga

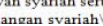

Dari data lapangan ini menunjukkan tingkat animo masyarakat yakni pelaku usaha/pedagang untuk berpastisifasi untuk mendirikan lembaga keuangan /BMT di pasar syariah ulul mendapatkan apresiasi yang cukup tinggi,ini dapat dilihat dari tinggi rasa ingin tahunya para pelaku usaha akan lembaga keuangan syariah pada saat sosialisasi, muncul pertanyaan dari pelaku usaha akan BMT, apa yang kami lakukan dan siap agar BMT bisa berdiri da nada di pasar syariah ulul albab ini serta pelaku usaha menyatakan kami siap mengumpulkan pedagang agar Menjadi anggota sekaligus pendiri BMT di pasar ini. Hal ini menjadi cacatan bagi kami tim pengabdian untuk bisa melakukan pendampingan untuk selanjutnya.

\section{KESIMPULAN}

Dari hasil pengabdian yang dilaksanakan pada pasar syariah ulul albab dengan mitra dengan adanya penyuluhan ini pada pelaku usaha yakni pedagang yang ada di pasar, sangat membantu para pedagang untuk lebih mengenal dan memahami untuk bisa mempraktekkan akan dari pentingnya lembaga keuangan syariah/BMT yang sesuai dengan syariah dan adanya keyakinan yang Tinggi dari para pedagang/pelaku usaha untuk segera mengaktualisasikan keinginan pelaku usaha/pedagang untuk bisa mendirikan lembaga keuangan syariah/BMT di lingkunga pasar syariah. Pada point lembaga keuangan syariah akan memberikan peluang kepada pelaku usaha/dagang untuk berpartisipasi padagang untuk mendirikan lembaga keuanga syariah/BMT, kegunaan dan akses akan BMT oleh padagang sudah pastinya akan sangat membantu usaha mereka.

\section{DAFTAR PUSTAKA}

[1] Anggraeni, L., Puspitasari, H., Ayubbi, S. El, \& Wiliasih, R. (2013). Akses UMKM Terhadap Pembiayaan Mikro Syariah Dan Dampaknya Terhadap Perkembangan Usaha: Kasus BMT Tadbiirul Ummah, Kabupaten Bogor The Access Of MSME Towards Islamic Microfinancing And Its Impact On Business Development : A Case Of BMT Tadbiirul Ummah, Jurnal Al-Muzara'ah, I(1), 56-67.

[2] Baskara, I. G. K. (2013). Lembaga Keuangan Mikro Di Indonesia. Jurnal Buletin Studi Ekonomi, 18(2), 114-125.

[3] Delima Sari Lubis. (2016). Pemberdayaan UMKM Melalui Lembaga Keuangan Syariah Sebagai Upaya Pengentasan Kemiskinan Kota Padangsidimpuan. At-Tijaroh, 2(2).

[4] Oktafia, R. (2017). Percepatan Pertumbuhan Usaha Mikro , Kecil Dan Menengah ( Umkm ) Melalui Perkuatan Lembaga Keuangan Mikro Syariah ( Lkms ) Di Jawa Timur. Proceedings Ancoms 2017 Percepatan Pertumbuhan UKM Renny Oktofia - UMS, (110), 85-92.

[5] Pertanian, P. A. S. E. Dan K. (2007). Peran Lembaga Mediator Dalam Membantu Penyediaan Modal Usaha Tani. Warta Penelitian Dan Pengembangan Pertanian, 29(2).

[6] Prastiawati, F., Darma, E. S., Akuntansi, P., Muhammadiyah, U., Selatan, J. L., \& Yogyakarta, D. I. (2016). Peran Pembiayaan Baitul Maal Wat Tamwil Terhadap Perkembangan Usaha Dan Peningkatan Kesejahteraan Anggotanya Dari Sektor Mikro Pedagang Pasar Tradisional, $17(2)$, Https://Doi.Org/10.18196/Jai.2016.0055.197-208

[7 Sholahuddin, S. M. Dan M. (2007). Peran Keuangan Lembaga Mikro Syariah Untuk Usaha Mikro Di Wonogiri. Proceeding Seminar Nasional Dan Call For Papers Sancall 2013 Surakarta, 23 Maret 2013, 300-309.

[8] Wita Dwika Listihana, Idel Waldelmi, A. A. (2019). Penyuluhan Permodalan Syariah Pada Pedagang Pasar Syariah Ulul Albab. Artikel.

[9] Zubair, M. K. (2016). Analisis Faktor-Faktor Sustainabilitas Lembaga Keuangan Mikro Syariah. IQTISHADIA, 9(2), 201226.

[10] https://www.gomarketingstrategic.com/produk-produklembaga-keuangan-syariah-baitul-maal-wat-tamwil-bmt/ 